\title{
PENERAPAN GAME DESIGN DOCUMENT DALAM PERANCANGAN GAME EDUKASI YANG INTERAKTIF UNTUK MENARIK MINAT SISWA DALAM BELAJAR BAHASA INGGRIS
}

\author{
Sri Lestari Rahayu', Fujiati $^{2}$ \\ ${ }^{1,2}$ Universitas Potensi Utama \\ Email: ${ }^{1}$ aiyu.lestari13@gmail.com,2fuji.potensiutama@gmail.com
}

(Naskah masuk: 12 Maret 2018, diterima untuk diterbitkan: 28 Juli 2018)

\begin{abstract}
Abstrak
Pentingnya belajar bahasa inggris pada usia dini dikarenakan bahasa inggris merupakan bahasa internasional. Metode belajar pada anak usia dini adalah belajar sambil bermain, anak-anak juga akan lebih mudah untuk menerima informasi dalam bentuk multimedia. Media pembelajaran yang interaktif akan membantu anak dalam menguasai pelajaran bahasa inggris sejak dini. Pada penelitian ini penulis membuat Game edukasi sebagai media pembelajaran yang interaktif. Dalam pembuatan game edukasi yang interaktif dibutuhkan perancangan Game Desain Document. Pada saat anak belajar dengan metode konvensional maka anak akan susah memahami dan cepat bosan karena anak belajar dari buku dan mendengarkan guru menjelaskan tetapi dengan adanya game edukasi sebagai media pembelajaran yang interaktif maka diharapkan akan memudahkan anak dalam mempelajari, memahami dan menguasai bahasa asing khususnya bahasa inggris. Aplikasi game yang dibangun menggunakan metode Game Design Document (GDD) dan metode perancangannya menggunakan metode waterfall. Adapun hasil dari penelitian ini berupa aplikasi media pembelajaran dan mendapatkan nilai presentase $80 \%$ dari kuesioner yang diisi oleh pengguna.
\end{abstract}

Kata kunci: Game Edukasi, GDD, Media pembelajaran, Interaktif, Konvensional.

\section{IMPLEMENTATION OF GAME DESIGN DOCUMENT IN DESIGNING INTERACTIVE EDUCATION GAMES TO INTEREST STUDENTS' INTEREST IN LEARNING ENGLISH}

\begin{abstract}
The importance of learning English at an early age because English is an international language. The method of learning in early childhood is learning while playing, children will also be easier to receive information in multimedia form. Interactive learning media will help children to master English language lessons early. In this study the author makes educational games as interactive learning media. In making interactive educational games, it is necessary to design a Document Design Game. When the child learns by conventional methods, the child will be difficult to understand and get bored quickly because the child learns from the book and listens to the teacher explaining but with the educational game as an interactive learning media it is expected to facilitate the child in learning, understanding and mastering foreign languages, especially English. Game applications are built using the Game Design Document (GDD) method and the design method uses the waterfall method. The results of this study are in the form of learning media applications and get a percentage value of $80 \%$ from the questionnaire filled in by the user.
\end{abstract}

Keywords: Game Education, GDD, Learning media, Interactive, Conventional.

\section{PENDAHULUAN}

Perkembangan pendidikan dan teknologi moderen, seharusnya berjalan bersamaan, kurikulum yang diberikan pada dunia pendidikan harus bisa mengaplikasikan teknologi terbaru. Seperti halnya metode dalam pendidikan, teknologi saat ini bisa digunakan dalam metode pendidikan.

Kebanyakan pendidik masih menggunakan metode pembelajaran yang bersifat konvensional, 
dimana peserta didik adalah penerima pengetahuan yang pasif, sedangkan pendidik sebagai pemberi informasi dan mengharapkan peserta didik untuk menghafal dan mengingat informasi yang diberikannya. Pembelajaran secara konvensional yang kurang menarik ini membuat peserta didik cenderung bosan dan tidak memahami apa yang disampaikan oleh pendidik.

Pembelajaran berbasis multimedia di dalam kelas dikembangkan atas dasar asumsi bahwa proses komunikasi di dalam pendekatan pembelajaran aktif (active learning) dapat memperkuat dan memperlancar stimulus dan respons anak didik dalam pembelajaran. Pendekatan pembelajaran interaktif dapat meransang indera penglihatan dan memperkuat daya ingat anak untuk mempelajari bahasa inggris. Salah satu contoh media pembelajaran yang disenangi oleh anak-anak usia dini yaitu game. Game merupakan salah satu contoh multimedia yang dapat dipadukan dengan pembelajaran yang biasa disebut dengan permainan dengan tujuan pembelajaran (education game).

Media pembelajaran yang interaktif dapat membantu seorang anak dalam memahami pelajaran yang diberikan, metode pembelajaran untuk anak usia dini juga belajar sambil bermain.

Game pada dasarnya merupakan permainan yang bersifat menyenangkan, menghibur. Dalam game, pendidikan diberikan lewat praktek atau pembelajaran dengan praktek (learning by doing). Sifat interaktif dalam game ini membuat game dapat digunakan sebagai sarana edukasi yang mempunyai fasilitas yang lebih baik dibandingkan dengan alat edukasi konvensional.

Pada penelitian sebelumnya dengan judul "Perancangan Aplikasi Game Edukasi Pembelajaran Anak Usia Dini Menggunakan Linear Congruent Method (LCM) Berbasis Android", (Tahun 2015) pada penelitian tersebut membangun sebuah aplikasi game edukasi pembelajaran anak usia dini berbasis android. Adapun metode yang digunakan yaitu linier congruent method. Hasil dari penelitian tersebut yaitu ketika melakukan kuesioner menghasilkan presentasi mencapai $78.33 \%$. Dengan nilai presentasi tersebut dinyatakan bahwa game yang dibangun sangat bagus.

Pada penelitian sebelumnya dengan judul "Game Edukasi Bahasa Indonesia Kelas 1 Sekolah Dasar Berbasis Android Menggunakan DGBL-ID Model" (Tahun 2017), pada penelitian tersebut membangun game edukasi Bahasa Indonesia berbasis android Bindo menggunakan DGBL-ID Model, dan telah berhasil dikembang sesuai dengan tahapan-tahapan yang ditentukan. Hasil uji coba pada aplikasi game tersebut adalah Mendapatkan prosentase usability rata - rata $84 \%$, information quality rata - rata $78 \%$, dan interaction quality rata - rata $82 \%$ yang berarti game tersebut berkualitas.

Pada penelitian sebelumnya dengan judul "Perancangan Game "Benar Atau Salahc(Studi
Kasus : SMK Miftahul Huda Rawalo) "Sebagai Media Pembelajaran Komputer Berbasis Android" (Tahun 2010), pada penelitian tersebut merancang game sebagai media pembelajaran komputer yang bertujuan untuk menambah minat belajar siswa dan meningkatkan nilai pada mata pelajaran KKPI dengan metode pengembangan sistem adalah metode MDLC.

Berdasarkan pemaparan diatas maka akan dirancang game edukasi yang interaktif untuk menarik minat siswa dalam belajar bahasa inggris. Perancangan game tersebut diharapkan akan memudahkan anak dalam mempelajari, memahami dan menguasai bahasa inggris. Pengguna dari aplikasi game tersebut adalah anak-anak yang didampingi oleh guru.

\section{METODE PENELITIAN}

Metode perancangan yang digunakan pada penelitian ini adalah metode waterfall. Tahapan yang ada pada metode waterfall yaitu requirements, design, implementation, verification, dan maintenance. Tahap-tahapan tersebut dapat dilihat pada Gambar 1 yang ada dibawah ini:

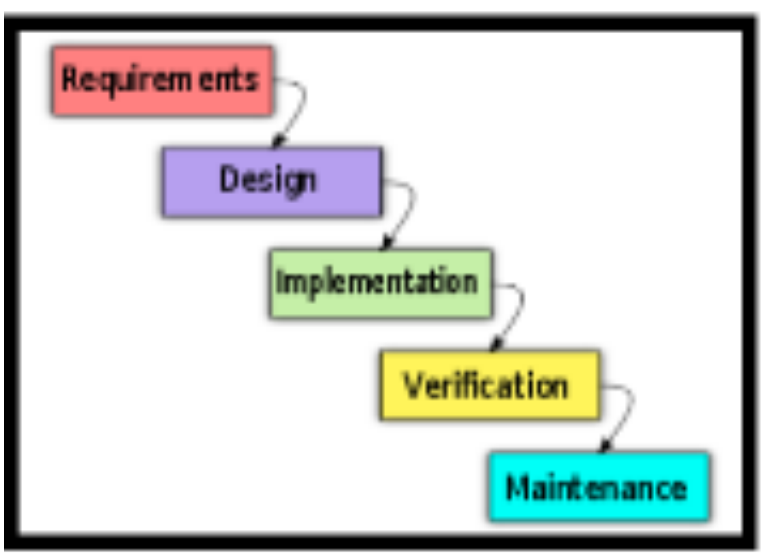

Gambar 1. Metode Waterfall

Berdasarkan tahapan-tahapan yang ada pada metode waterfall, berikut adalah penjelasan dari tahapantahapan dari metode waterfall dalam perancangan game edukasi yang interaktif untuk menarik minat siswa dalam belajar bahasa inggris:

1. Requirement (analisis kebutuhan)

Pada tahap ini membahas tentang analisis yang dibutuhkan dalam game dan menentukan material-material dan data-data yang diperlukan dalam pembuatan game.

2. Design (Perancangan)

Pada tahap ini adalah tahap pembuatan spesifikasi meliputi arsitektur program, gaya, tampilan dan kebutuhan material atau bahan untuk membuat game edukasi interaktif. Tahap design yang dilakukan dapat meliputi 
perancangan use case, flowchart dan kebutuhan perangkat yang digunakan.

Berikut adalah flowchart (diagram alir) dalam perancangan game edukasi yang digunakan untuk menarik minat siswa dalam belajar bahasa inggris. Flowchart (diagram alir) tersebut dapat dilihat pada Gambar 2 dan use case dapat dilihat pada Gambar 3.

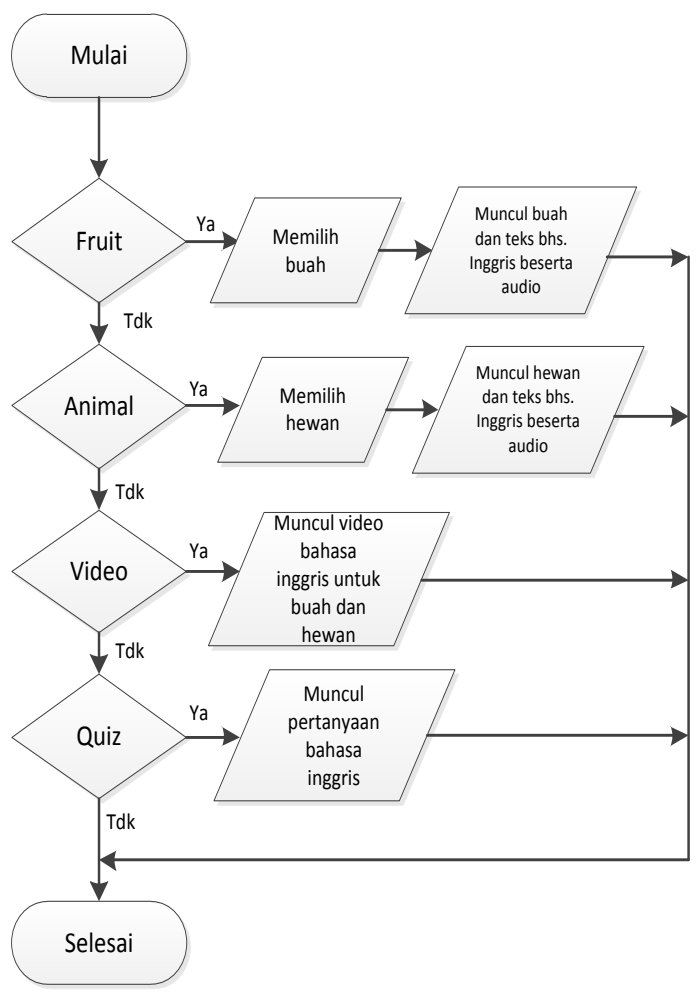

Gambar 2. Flowchart Game Edukasi

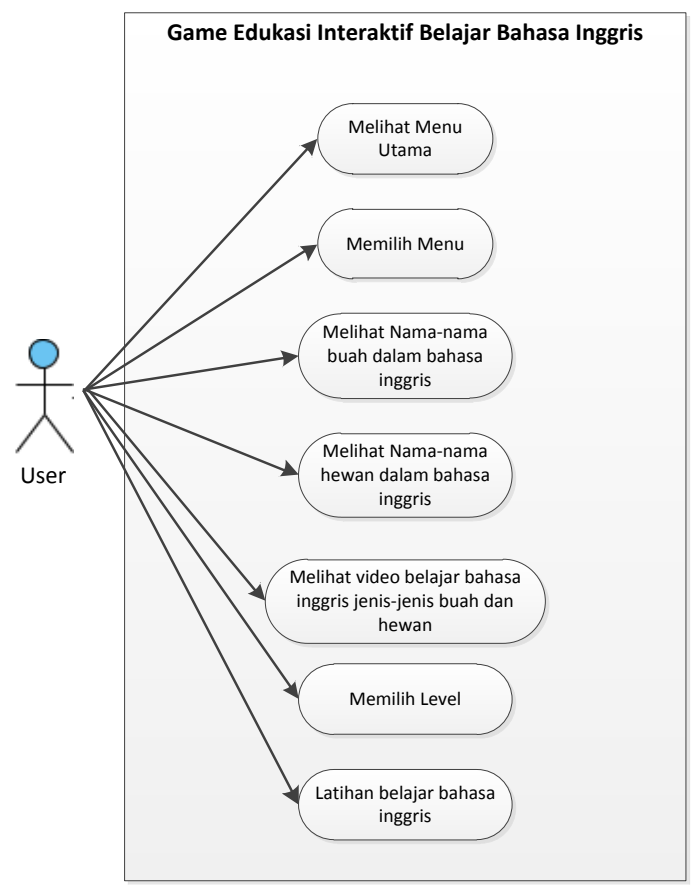

Gambar 3. Usecase Game Edukasi

\section{Implementation}

\section{1 Мепи Ноте}

Menu Home merupakan tampilan awal yang muncul ketika aplikasi tersebut dijalankan. Pada tampilan ini terdapat beberapa menu pilihan sesuai kategori pilihan belajar bagi anak-anak yang dilengkapi dengan suara sebagai petunjuk. Berikut merupakan tampilan menu utama pada game edukasi yang ada pada Gambar 4 dibawah ini.

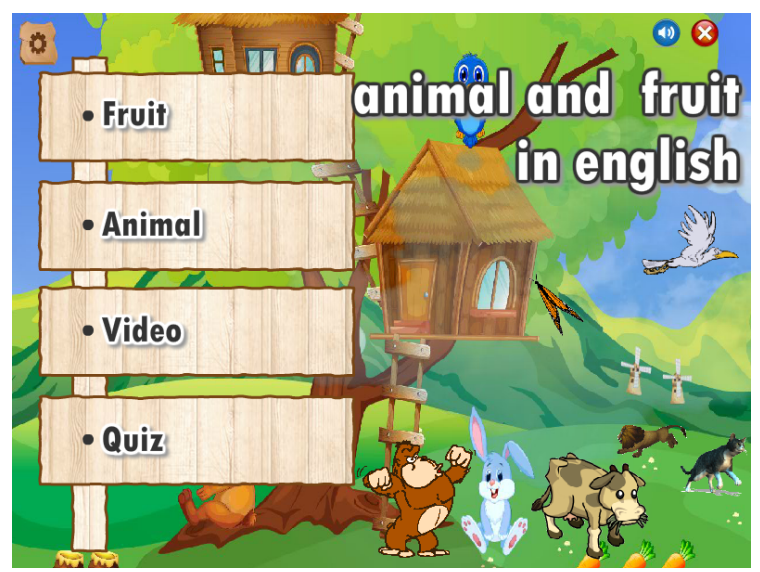

Gambar 4. Menu Home

\subsection{Menu Fruit}

Menu fruit merupakan tampilan yang berisikan kosakata nama-nama buah dalam bahasa inggris, pada saat user memilih salah satu objek buah yang tampil maka akan muncul tampilan objek buah yang dipilih, selain itu muncul pula audio dari terjemahan buah tersebut dan teks terjemahan bahasa inggris buah tersebut. Berikut merupakan tampilan memilih buah pada game edukasi yang ada pada Gambar 5 dibawah ini.

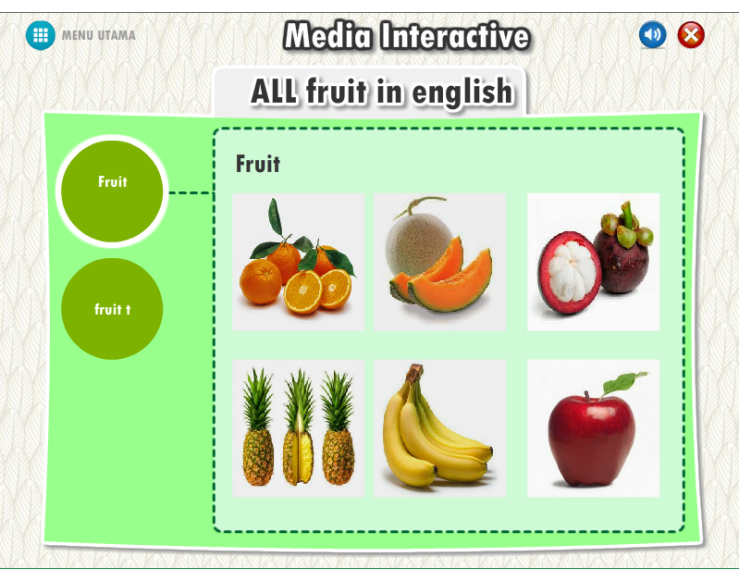

Gambar 5. Memilih Buah

\subsection{Menu Video}

Pada menu video tersedia sub menu fruit dan animal. Menu buah berisikan video nama-nama 
buah dalam bahasa inggris, pada video tersebut anak-anak dapat belajar bahasa inggris dalam bentuk singular dan flural. Pada video tersebut berisi gambar buah, audio (suara) dari terjemahan buah tersebut, teks terjemahan bahasa inggris hewan tersebut. Berikut merupakan tampilan memilih video pada game edukasi yang ada pada Gambar 6 dibawah ini.

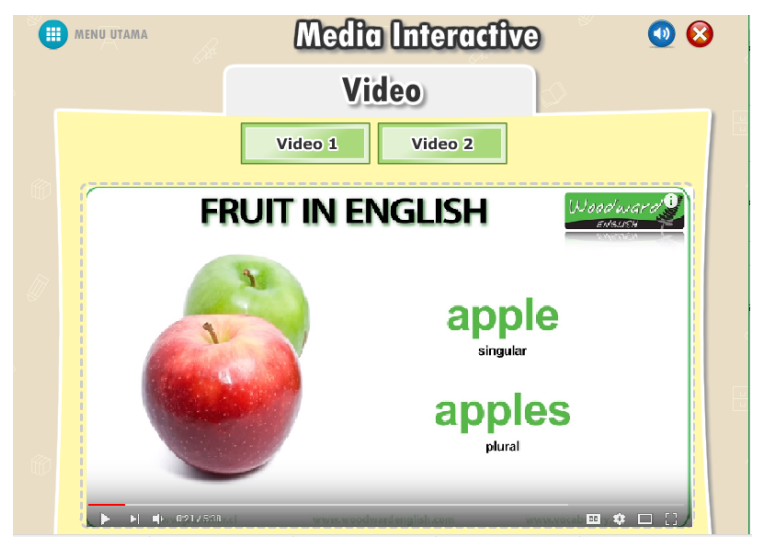

Gambar 6. Memilih Video

\subsection{Menu Quiz}

Setelah anak-anak belajar nama-nama buah dan hewan dalam bahasa inggris kemudian user menuju ke menu quiz untuk menjawab pertanyaan dalam bahasa inggris. Pertanyaan tersebut berisi tentang terjemahan bahasa inggris buah dan hewan. Jawaban diberi petunjuk untuk memudahkan anak-anak dalam menjawab pertanyaan. Gambarnya dapat dilihat dibawah ini.

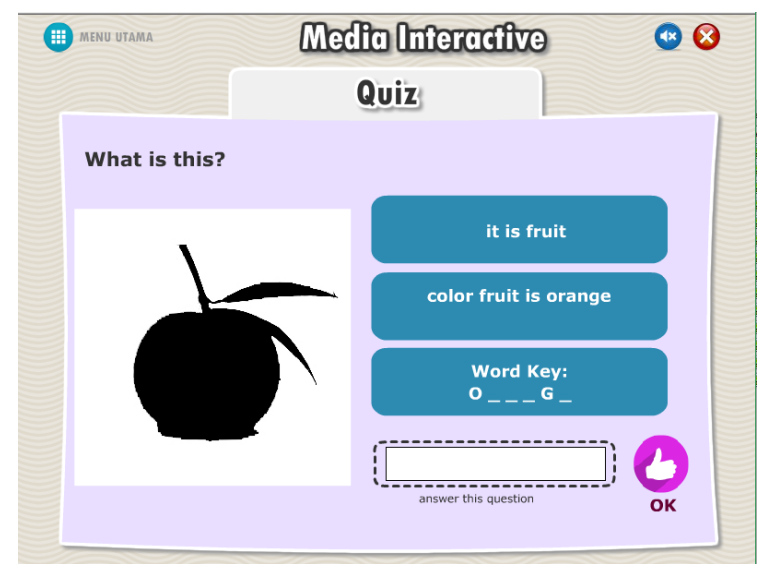

Gambar 7. Мепu Quiz

4. Verification (Pengujian dan Integrasi)

Tahapan ini bisa dikatakan sebagai final dalam proses pembuatan sebuah sistem. Yaitu tahap verfikasi oleh pengguna. Pengguna akan menguji apakah aplikasi yang dibuat sudah sesuai dengan yang diharapkan. Pengujian dilakukan oleh pengguna dengan mengisi kuesioner yang diisi oleh pengguna ketika selesai menggunakannya. Pengguna yang dimaksud pada tahap ini adalah guru. Karena Guru dapat merasakan hasil pemahaman anak dari perbedaan penggunaan metode media pembelajaran dengan metode konvensional. Guru yang mengisi kuesioner adalah guru yang sebelumnya mendampingi siswa saat menggunakan game edukasi interaktif. Kuesioner yang diisi oleh guru mencakup pertanyaan mengenai pembangunan game edukasi.

Berikut adalah pertanyaan-pertanyaan yang harus dijawab oleh pengguna.

Tabel 1. Pertanyaan Pada Kuesioner

\begin{tabular}{cl}
\hline no & \multicolumn{1}{c}{ pertanyaan } \\
\hline 1 & Apakah game ini menarik? \\
2 & Apakah animasinya menarik? \\
3 & Apakah suara terdengar jelas? \\
4 & $\begin{array}{l}\text { Apakah game ini membuat termotivasi untuk } \\
\text { belajar? }\end{array}$ \\
5 & Apakah petunjuk penggunaan sudah jelas? \\
6 & Apakah pemilihan warna terlihat menarik? \\
7 & $\begin{array}{l}\text { Apakah pemilihan teks terlihat menarik? } \\
\text { Apakah muncul rasa antusias saat menggunakan } \\
\text { game edukasi interaktif tersebut? }\end{array}$ \\
9 & $\begin{array}{l}\text { Apakah pertanyaan yang ada pada menu quiz } \\
\text { sudah sesuai dengan materi ajar pada menu video }\end{array}$ \\
& $\begin{array}{l}\text { Apakah menu yang tersedia sudah memenuhi } \\
\text { kebutuhan? }\end{array}$ \\
\hline
\end{tabular}

Kemudian hasil kuesioner dihitung dengan menggunakan skala likert. Rumus skala likert yang digunakan yaitu:

\section{Rumus : T x Pn \\ $\mathrm{T}=$ Total jumlah responden yang memilih Pn $=$ Pilihan angka skor likert}

Berikut merupakan tampilan hasil kuesioner yang diisi oleh pengguna yang didampingi oleh guru untuk game edukasi yang ada pada Gambar 8 dibawah ini.

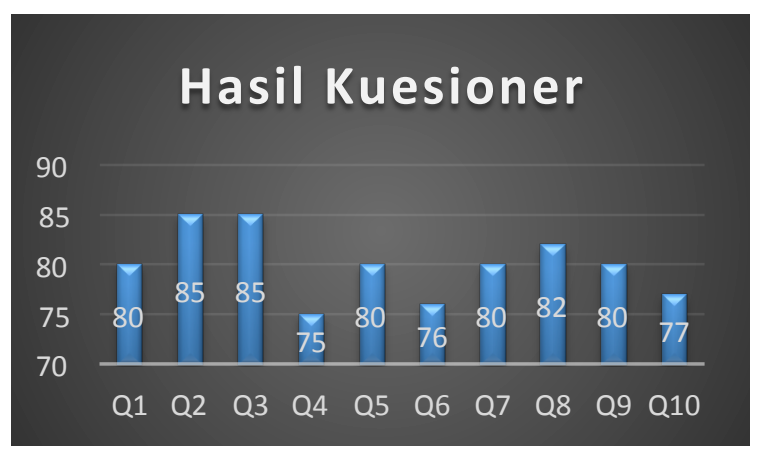

Gambar 8. Hasil kuesioner

Pada gambar diatas merupakan hasil kuesioner yang diisi oleh pengguna. Untuk Q1 (Pertanyaan 1) mendapatkan nilai 80, Untuk Q2 (Pertanyaan 2) mendapatkan nilai 85, Untuk Q3 (Pertanyaan 3) mendapatkan nilai 85, Untuk Q4 (Pertanyaan 4) mendapatkan nilai 75, Untuk Q5 (Pertanyaan 5) mendapatkan nilai 80, Untuk Q6 (Pertanyaan 6) 
mendapatkan nilai 76, Untuk Q7 (Pertanyaan 7) mendapatkan nilai 80, Untuk Q8 (Pertanyaan 8) mendapatkan nilai 82, Untuk Q9 (Pertanyaan 9) mendapatkan nilai 80, Untuk Q10 (Pertanyaan 10) mendapatkan nilai 77. Dari hasil tersebut didapatkan nilai rata-rata yaitu $80 \%$.

5. Maintenance (Pemeliharaan)

Tahap berikut merupakan akhir pengembangan sistem pada model waterfall. Pemeliharaan yang termasuk diantarannya proses perbaikan sistem jika ada kesalahan atau error.

\section{PEMBAHASAN}

Berdasarkan metode pengembangan GDD (Game Design Document) yang terdiri atas game overview, genre, target audience, look and feel, feature set, Mission/challenge/tantangan, reward dan play flow.

a. Game Overview, membantu anak dalam belajar bahasa inggris dengan menggunakan media pembelajaran interaktif.

b. Genre, media pembelajaran yang dirancang bergenre education game.

c. Target Audience, Target utama/ pengguna dari aplikasi tersebut yaitu anak-anak. Game tersebut dapat dijadikan media pembelajaran bahasa inggris untuk anak-anak usia dini.

d. Look and Feel, education game dirancang semenarik mungkin yaitu dengan menggunakan warna-warna yang terang dan adanya penambahan suara sehingga anak lebih termotivasi untuk belajar bahasa inggris.

e. Feature Set, game tersebut memiliki beberapa fitur yang ditawarkan.

\section{- Main Menu :}

1) Мenu Fruit, menu tersebut berisi berbagai jenis buah-buahan, ketika salah satu buah tersebut diklik maka akan muncul teks bahasa inggris buah tersebut beserta suaranya.

2) Menu Animal, menu tersebut berisi berbagai jenis hewan, ketika salah satu hewan tersebut diklik maka akan muncul teks bahasa inggris hewan tersebut beserta suaranya.

3) Menu Video, menu tersebut berisi video jenis buah-buahan dan hewan dalam bahasa inggris bentuk plural dan singular.

4) Menu Quiz, menu tersebut berisikan quiz/pertanyaan mengenai pembelajaran bahasa inggris untuk nama-nama buah dan hewan yang terdiri dari beberapa level. f. Mission, Challenge, Tantangan, pada game tersebut berisikan level yang berawal dari level 1, kemudian menjawab pertanyaan terjemahan bahasa inggris dari objek yang muncul.

g. Reward, reward yang diterima oleh pengguna yaitu bisa membuka level berikutnya jika pertanyaan pada level sebelumnya sudah terjawab.

h. Play Flow, cara bermain sudah ada pada menu help. Pemain dapat mengetahui cara menggunakan game edukasi interaktif dan cara menjawab quiz yang tersedia.

\section{KESIMPULAN}

a. Perancangan game edukasi dapat diterapkan pada anak-anak usia dini yang didampingi oleh guru dengan menggunakan metode GDD (Game Design Document) yang terdiri atas game overview, genre, target audience, look and feel, feature set, Mission / challenge / tantangan, reward dan play flow.

b. Game edukasi interaktif tersebut dapat digunakan oleh anak-anak usia dini yang didampingi oleh guru dalam mempelajari bahasa inggris khususnya nama-nama buah dan hewan.

c. Pada Hasil kuesioner uji coba game edukasi interaktif terhadap siswa yang didampingi oleh guru mendapatkan presentase rata-rata 80\% (Predikat "Baik"). Oleh karena itu, aplikasi game tersebut mampu membantu anak dalam memperkaya kosa kata namanama buah dan hewan dalam bahasa inggris.

\section{DAFTAR PUSTAKA}

FAUZI, M., RINDA C,. DEWI T,. 2013. Pembuatan Game Edukasi Pengenalan Karies Untuk Anak Usia 6-8 Tahun. Jurnal Algoritma: ISSN :2302-7339 Vol.10 No.15.

DORA, I., RITA W,. SRI P,. 2015. Perancangan Aplikasi Game Edukasi Pembelajaran Anak Usia Dini Menggunakan Linear Congruent method (LCM) Berbasis Android. Jurnal Informatika: ISSN :2477-3786 Vol.6 No.1.

DIAN, WP., PRASITA N,. ERRI WP,. 2016. Game Edukasi Berbasis Android Sebagai Media 
Pembelajaran Untuk Anak Usia Dini. JIMP: ISSN :2502-5716 Vol.1 No.1.

HIMSYARI, AM., 2017. Game Edukasi Bahasa Indonesia Kelas 1 Sekolah Dasar Berbasis Android Menggunakan DGBL-ID Model. Integer Journal: Vol.2 No.1.

ADE, S., 2010. Perancangan Game "Benar atau Salah" Sebagai Media Pembelajaran Komputer Berbasis Android. Jurnal Telematika: Vol.3 No.1.

PUJI, H., SUYANTO, HANIF A. F., 2015. Perancangan Game Design Document Serious Game Permainan Tradisional Angklek Sleman Yogyakarta.Seminar Nasional Informatika.

HALIMATUS, S., FAHIM N.C.B., ALFIAN Z.K.P, 2017. Analisa Kebutuhan Pada Pembuatan Template Game Design Document. Jurnal Telematika: ISSN: 2085-2347, Vol.9 No.1.

ROSA D., NEVI K. A.., BRAMASTI K., 2015. Identifikasi Kebutuhan Pengguna Untuk Aplikasi Permainan Edukasi Bagi Anak Usia 4 Sampai 6 Tahun. Jurnal Teknik Informatika dan Sistem Informasi: ISSN: 2443-2229, Vol.1 No.1.

AUliA H., M. SUYANTO, SUKOCO., 2017. Perancangan Game Petualangan Membatik Berbasis Model Pembelajaran Teams Games Tournaments. Jurnal Telematika: ISSN: 2442-4528, Vol.10 No.1.

KOMANG A., I GEDE M., GEDE A., 2018. Pengembangan Aplikasi Game Musik Tradisional Bali Megamelan Berbasis Multiplatform: e-ISSN: 2528-6579, Vol.5 No.1.

FORDA, ARNOLDI, 2016, Rancang Bangun Aplikasi Game Edukasi Pembelajaran Aksara Lampung "Ajo Dan Atu - Belajar Aksara Lampung", Berbasis Android Dengan Sistem Multi-Ending Menggunakan Engine Ren'Py. Jurnal Teknologi Informasi dan Ilmu Komputer, Vol.3 No.4, hal 238-247 